\title{
East European Refugee Symposium
}

On March 29, 1990, the Centre for Refugee Studies organized a symposium at Osgoode Hall Law School, York University, to discuss the Canadian policy towards Eastern Europeans seeking to come to Canada as refugees under the current rapidly-changing circumstances. Participants were invited to express their own opinions based on their knowledge and not to represent any organizational views. Further, it was agreed that there would be no attribution of comments. Nor would the meeting be reported, though the results could be. In any case, there was no commitment by anyone to endorse the results. The intention was to encourage a free exchange of information and ideas without inhibition.*

\section{The problem}

Everyone agreed that the problem of the movement of East Europeans as refugees was a complex and multifaceted one in which simplicity or deformation by selection of one or two aspects does an injustice to the issue. The following factors seemed to constitute most of the key items:

\section{The altered political situation}

With the relaxation of any exit restrictions (with the exception of Albania), and with the sudden transformation of Hungary, Czechoslovakia, Poland, Romania and Bulgaria into democracies or, at least into countries on the path to becoming democracies, and the institutionalizing of glasnost in the Soviet Union, the auto- matic right to refugee status and asylum for anyone leaving the Eastern Bloc was, at the very least, questionable.

\section{The changing economic situation}

As the Eastern Bloc economies begin to go through some radical changes as a result of the lengthy economic stagnation and the structural shifts involved in radical economic transformation, many people may want to leave for economic reasons.

\section{Numbers outside their home country}

Other than East Germans, the largest national group living outside their homeland consists, according to one of the participants at the sympo-

\footnotetext{
* Those attending included Howard Adelman, Director, Centre for Refugee Studies, York University; Janek Ajzner, doctoral candidate, Sociology, University of Toronto; Andre Batko, psychologist, Polish Social Services; Deyaniia Benavides, Community Legal Services, Welland; immigration lawyer Richard Boraks; Eugen Duvalko, Canadian Ukrainian Immigration Society; Anna Dymek, Multicultural Centre, Mississauga; Andrew Goodman graduate student, Political Science, York University; Paul Kaihla, Associate Editor, Maclean's Magazine; Theresa Kott, sociologist; Sister Alice Kwiecien, sponsorship organizer; Joe Mackenzie, graduate student, Social and Political Thought, York University; Nestor Mykytyn, Canadian Ukrainian Immigration Society; John Oostrom, MP; and Peter Skeris, Polish Alliance Press.
}

sium, of about 300,000 Poles. Of these, 150,000 are in West Germany, a large number in Italy, smaller numbers in Greece and a build-up beginning in Turkey. By contrast, there are only 1,000 Ukrainians; and 600 of these already have sponsorships in place. Most East Europeans in this group fled their home countries before the dramatic changes of the last six months. They are part of what will be referred to henceforth as the European backlog.

\section{Families}

Included among the East Europeans throughout Europe are families with children. A serious problem arises becausue the education of these children is at a standstill.

\section{Canadian immigration number}

Some people in the backlog have received a number from the Canadian immigration authorities in Europe and are at different stages of the interview, medical and security checking process but some in West Germany are being pushed out before the process is completed as Germany attempts to cope with the huge influx of East Germans. 


\section{Convention refugees}

Individuals in the Eurpean backlog are attempting to come to Canada as humanitarian refugees under the Designated Class category as self-exiles. Given the tremendous backlog, the immanent possibility (and likelihood) that Canada may follow the Australian and American lead and end any special designation of East Europeans as humanitarian refugees, many of these have been taking advantage of the new ease in exiting and the direct route to Canada. East Europeans, particularly Bulgarians and Poles, have begun to arrive in Gander in much larger numbers than the processing system, the welfare system or even the hotel system can handle. Further, they do not appear at first glance as genuine Convention refugees, and the impression is given that these refugee claimants are abusing the system.

\section{Alternatives}

Though the alternative of asylum in European countries is less and less likely, repatriation is now physically and politically possible without apparent risk to the vast bulk of the claimants, certainly from Eastern Europe. Further, in the case of Hungarians fleeing Romania, Hungary had become a signatory to the Geneva Convention and Hungary could now be expected to take in the vast bulk of Hungarians from Romania if a mass movement does begin.

\section{Risks}

But there are some risks. Though democracies may be well on the way to establishing themselves, even if on a shaky foundation, many argued that the old appartchniks of the Communist party still hold power in the countryside and, more importantly, use that power to put individuals at risk. Further, there is a new source of danger: inter-ethnic strife with the rise of old nationalistic animosities. Since economic problems are likely to get worse before they get better, inter-ethnic disputes can be expected to increase. Most participants felt that the USSR was in a separate category because it was still not a democracy in spite of glasnost. As the Lithuanian situation exemplified, glasnost was subject to being turned off to suit the Kremlin when it was under threat. Finally, specific ethnic groups in the Soviet Union, and sometimes elsewhere, who lacked a distinctive national homeland in those countries (Jews) or where the national homeland was somewhat unsafe (Armenians) might be particularly at risk, mainly if individuals from such groups were involved in the old political structures.

\section{Lack of previous and current opportunity}

One of the clearest problems which directed those leaving Eastern Europe into the refugee stream was not the fear of persecution at the present time, but the lack of opportunities to apply to migrate given the absence of visa officers in Eastern Europe. Further, since families had been separated for years, even decades, there was a huge build-up of demand which the drop in barriers has allowed to move. But the absence of visa officers has not been able to facilitate this movement.

\section{Humanitarian issues}

Even if these East Europeans were by and large not Convention or even humanitarian refugees, there was still a moral concern for those wasting their productive years in camps and the lack of opportunities for their children to attend school; the fact that these migrants would have virtually nothing if they did return to their countries of origin, a problem which would be exacerbated by the economic problems involved in restructuring, made their claims particularly poignant. Further, there was also the humanitarian factor of the long years their relatives were unable to bring them over while other Canadians were able to sponsor theirs. This left East Europeans with the conviction that they had a claim to special consideration.

\section{Sponsorship}

Under the current system, as long as the individuals in Europe were eligible to come as Designated Class immigrants, there was not supposed to be a quota or limit on the numbers sponsored. On the other hand, everyone experienced a limit, whether that limit resulted from the limited funds available for interest free loans for transit, the lack of personnel to process applications and undertake the security checks or for other reasons. Further, there was a difference in perception when Poles or Ukrainians in Europe advance funds to Canada to facilitate their own sponsorships. Whereas some federal officials viewed this as a corrupt practice totally at odds with the intent of private sponsorship, East Europeans saw this as a guarantee of successful re-establishment at great saving to Canadians.

\section{The Canadian dimension}

Though there was some focus on the ways to help these people improve in their speed and ability to resettle by undertaking such programs as language training while they sat in camps in Europe, the major question that emerged was over the reputation of the ethnic group in Canada. They did not like being portrayed as being engaged in corrupt practices when what they did was open and above board. They did not like the use of such language as "overwhelming numbers" which created a false impression when the numbers were really not that great in absolute terms. Any program should have as one feature an effort to rehabilitate the reputation of the community and, at the very least, inhibit any aspersions on their integrity. 


\section{Criteria for resolving the problem}

\section{Fairness}

It was agreed that if the present program was unfair in putting a group into the refugee category, either by guiding them into the Convention refugee claims system or continuing to regard most of them as designated classes when the category was no longer applicable, this would be unfair and should be discontinued.

\section{Universalism}

Any changes which were made to meet the needs of the East Europeans should be available to other groups in the same situation.

\section{Unpredictability}

Any changes should take into account the highly volatile situation in Eastern Europe and be prepared to reinstate programs that are discontinued.

\section{Feasibility}

It was recognized that there were pragmatic factors that influenced and affected the role the Canadian government was willing to play - costs, numbers, percentage of burden sharing, etc.

\section{Reputation}

Any changes which take place should take into account the responsibility of protecting any particular ethnic group from any aspersions on its reputation.

\section{Recommendations}

The recommendations were seen to be part of a package since the implementation of one without introducing another would be seen as both unworkable and totally unfair. For example, if most of the East European nations are dropped from the class of those eligible to be taken in as humanitarian refugees under the self-exiled designated class category without, at the same time, introducing immigration visa officials into Eastern Europe and, preferably, introducing a bonus system to make up for lost opportunities in the past, then the changes would both be regarded as unfair and attempts would continue to undermine existing systems such as the inland refugee determination system.

\section{The self-exiled class}

This category should remain as part of the laws in Canada.

\section{Countries eligible for obtaining self-exiled status}

Hungary, Poland, Czechoslovakia, Romania and Bulgaria shouid be deleted from the list. While most were not yet prepared to delete the USSR, one participant wanted to go on record as objecting to any exception being made for the Soviet Union since the dangers for persecution per se were not significantly different than in the East European states and the Soviet citizens were now more or less free to apply to leave. There was agreement that Albania should remain on the list. The union of East Germany with West Germany would resolve that problem for the Germans.

\section{Alternatives}

Though settlement in countries of first asylum was understandable and appropriate for some ethnic groups (Hungarians from Romania) and repatriation might be the reality for others (e.g. Poles), the ethnic groups did not want to participate or be seen to be endorsing a program of repatriation and certainly not facilitate such repatriation with financial assistance, quite aside from whether such a solution was reasonable or just, simply because of the way repatriation, with its historical resonances, was perceived in the ethnic communities from Eastern Europe.

\section{Refugee determination}

Though refugee claimants from Eastern Europe arriving in Canada and claiming refugee status were very unlikely to be Convention refugees, and though they were contributing to the gumming up of the refugee claims system, a fact which could rebound to the discredit of their local ethnic communities, the communities did not believe their active participation in a campaign, through advertisements or other means, even if subsidized by the Government, would be effective or accepted by the respective communities.

\section{European backlog}

Special consideration should be given to those already in the backlog, particularly those who have already begun the process of applying to come to Canada and particularly those families with children.

\section{Numbers}

If the numbers total 300,000 and Canada's historic role in burden-sharing varied from 10 per cent to 25 per cent, Canada should assume its normal share of the burden of taking these people into Canada.

\section{Humanitarian bonus immigration points}

The most original recommendation that emerged from the seminar was that these people no longer be dealt with as self-exiled, except for those already in process under the old rules, but should be dealt with as immigrants. Only special extra humanitarian points should be granted to any immigrant applicant who, because of the past restrictions of his/her native state, was unable to 
apply for immigrant status and, further, was currently in exile because of that policy and practice. These humanitarian bonus points would be available to any immigrant applicant from anywhere so long as the immigrant fulfilled the criteria. The number of points granted would be a product of the estimated numbers Canada felt should be part of its burden and the amount needed to be allocated to achieve that objective.

\section{Immigration visa officers}

Immigration offices and visa officers should be set up immediately in all the East European states.

\section{Financing additional officers}

Since there are budget constraints which are quite understandable, three practices should be introduced to save money in the overall immigration program to allow funds to be re-allocated to Eastern Europe. Locals should be hired at local rates of pay as support staff. Secondly, real rather than official exchange rates should be used in obtaining monies to run local external affairs offices. Thirdly, the immigration system should be operated as a user-pay system so that visa and other charges pay for the operation of the system.

\section{A study}

Consideration should be given to a study of Poles who previously resettled in Canada, particularly the success of resettlement, the costs of private versus public sponsorship, the rate of repayment of transportation loans and the number of defaults, the role of ethnic organizations in facilitating such movements and its objectives. The point of such a study would not only be to clarify a number of facts which are in dispute, but to bring all facts in the open so that misperceptions could be avoided.

\section{Implementation}

\section{Publication}

It was agreed that the Report of the Symposium should be published in Refuge.

\section{Distribution}

It was agreed that the Report of the Symposium should be distributed to participants who would be free to use it as they see fit.

\section{Government}

It was agreed the Report should be sent to the Government with the suggestion that the Government convene an official meeting with representatives from East European ethnic groups, and the recommendations of the Report be used as an agenda for a consultation.

\section{New Publication}

The English version of the International Thesaurus of Refugee Terminology (Dordrech: Martinus Nijhoff Publishers, 1989) has been published under the auspices of the International Refugee Documentation Network with the help of a grant from Ottawa's International Development Research Centre.

This first volume of an ambitious multilingual project was prepared by Jean Aitchison, Coordinator of the Refugee Thesaurus Working Group.

As the introduction aptly indicates, it is expected that the thesaurus will contribute to the performance of the International Refugee Documentation Network by improving the speed and consistency of indexing and easing the intellectual effort of searching by controlling synonyms, and displaying broader, narrower and related terms needed to extend or refine a search. With the thesaurus there should be a higher rate of recall of the relevant documents in the databases or documentation files and more effective prevention of the retrieval of unwanted items.

The thesaurus is to be published in three separate volumes, corresponding to the three languages being used, English, French and Spanish. The English edition is issued first followed by the French and Spanish editions, produced respectively by Documentation Réfugiés (Paris) and Latin
American Information Center on Migration (Santiago de Chile). The English edition was slightly modified to meet equivalence difficulties in the other two languages.

While the thesaurus is intended primarily for use by organizations which are active in documentation work concerning refugees, in particular the current and future members of the International Refugee Documentation Network, it will also serve well a wide spectrum of other users. Because of its multilingual context, and the specific inclusion of French/English/ Spanish and Spanish/ English/French indexes, the Inter-national Thesaurus of Refugee Terminology will also prove an invaluable tool to interpreters and translators dealing with refugeerelated matters.

A spartan desktop publishing effort, the International Thesaurus of Refugee Terminology will definitely prove its worth as a reference book. It is to be hoped that its versatility will allow it to keep pace in future editions with the growing development of new terms as witnessed for example during the day-to-day proceedings of Canada's own refugee determination process.

The thesaurus is available in Canada and the US from Kluwer Academic Publishers, 101 Philip Drive, Norwell, MA 02061, USA. 